\title{
Agricultural Holdings' Impact on the Rural Development. Case Study: Romania
}

\author{
Romeo Victor Ionescu ${ }^{1}$, Monica Laura Zlati ${ }^{2}$, Valentin Marian Antohi ${ }^{3,4, *}{ }^{\circ}$, Andrei Mirel Florea ${ }^{5}($, \\ Florentin Bercu ${ }^{6}$ and Florin Marian Buhociu ${ }^{7}$
}

check for

updates

Citation: Ionescu, R.V.; Zlati, M.L.; Antohi, V.M.; Florea, A.M.; Bercu, F.; Buhociu, F.M. Agricultural Holdings' Impact on the Rural Development. Case Study: Romania. Agronomy 2021, 11, 2231. https://doi.org/10.3390/ agronomy11112231

Academic Editors: Riccardo Testa, Giuseppina Migliore,

Giorgio Schifani and József Tóth

Received: 3 October 2021

Accepted: 29 October 2021

Published: 3 November 2021

Publisher's Note: MDPI stays neutral with regard to jurisdictional claims in published maps and institutional affiliations.

Copyright: (c) 2021 by the authors. Licensee MDPI, Basel, Switzerland. This article is an open access article distributed under the terms and conditions of the Creative Commons Attribution (CC BY) license (https:/ / creativecommons.org/licenses/by/ $4.0 /)$.
1 Department of Administrative Sciences and Regional Studies, Faculty of Juridical, Social and Political Sciences, Dunărea de Jos University, 800008 Galaţi, Romania; ionescu_v_romeo@yahoo.com

2 Department of Accounting, Audit and Finance, Faculty of Economics, Administration and Business, Ştefan cel Mare University, 720229 Suceava, Romania; sorici.monica@usm.ro

3 Department of Business Administration, Faculty of Economics and Business Administration, Dunărea de Jos University, 8000008 Galaţi, Romania

4 Department of Finance, Accounting and Economic Theory, Faculty of Economic Sciences and Business Administration, Transylvania University, 500036 Braşov, Romania

5 Department of Materials and Environmental Engineering, Faculty of Engineering, Dunărea de Jos University, 800008 Galaţi, Romania; floreaandreim@yahoo.com

6 Union of the National Branch of Crop Sector Cooperatives, 020491 Bucharest, Romania; florentinbercu@gmail.com

7 Department of Economics, Faculty of Economics and Business Administration, Dunărea de Jos University, 800008 Galaţi, Romania; familia_buhociu@yahoo.com

* Correspondence: valentin_antohi@yahoo.com

Abstract: Associative forms represent a part of the agricultural producers' manifestation, with long-term impact on rural development. Considering the current dimension and the culturalorganizational baggage, the authors aim to carry out an impact study on the contribution of agricultural holding companies to rural development. This objective is to be achieved through prospective analysis methods based on a structured questionnaire, which allows for statistical tests of the variables' frequency and representativeness and econometric modelling of rural development efficiency in relation to independent variables related to the organizational custom and economic outputs of organizations. The results of the study aim at identifying the vulnerabilities that hinder the maximization of the function of the agricultural holding companies (the economic development) and treating these vulnerabilities through some concrete measures according to the modelling results. The study is useful for rural policy makers and trainers in any country in the world.

Keywords: rural development; agriculture holding; econometric model; vulnerabilities; sustainability

\section{General Approach}

Associative forms represent an approach to agricultural management that aims at both rural development and increasing performance at the branch level by applying production management and marketing procedures adapted to the mechanisms of the modern economy, with global trade flows and connections on the stock management and production. Although it is an innovative concept, cultural differences can have a significant impact on these forms of organizing agricultural activity, differences that can make the distinction between failure and success. Interconnection with the administrative apparatus was used in Romania as a way of support to compensate for the material and management deficiencies of the branch. With integration into the European common space, a number of rules and principles have been adopted and have somewhat limited the application of these aid schemes.

In Romania, rural development is a combination of economic and administrative activities that seek economic, social, cultural development against the background of 
European funding under the CAP's Second Pillar (Common Agricultural Policy) and government funding.

In this equation, the associative forms play a productive regulatory role, using by association resources for productive purposes. They have a social role by ensuring the absorption of the labor and contribute to the national and regional budget by paying taxes and duties.

This paper aims to analyze the efficiency of the associative forms and their direct impact on the rural economic dimension at the qualitative level (by influencing the policies of cooperation, cohesion and harmonization of the legislative framework necessary to carry out these types of activities). The quantitative dimension reflects the market economic capacity, the study revealing that the contribution of some economic agents can be measured by financial indicators (such as turnover of over 1 million euros per year, profit made), by participating in the foreign trade and by providing logistics chains between Romanian producers and processors.

The objectives of the study are:

O1: Determining the result elements regarding the efficiency of the associative forms, which contribute intrinsically to rural development in Romania;

O2: Evaluating the efficiency of these elements by conceptualizing an econometric model of correlation regarding holding efficiency and rural development;

O3: Identification of vulnerabilities that affect the function of maximizing the development of holdings on rural development;

O4: Quantification of the rural development measures that reduce the identified vulnerabilities and maximize the development function;

O5: Identifying the role of financial support for the development of holding companies and rural development.

The motivation of this study lies in identifying the main vulnerabilities which prevent this form of organization from maximizing its economic function as a pole of rural development, as happens in advanced economies such as France and Germany.

\section{Literature Review}

In order to determine the theoretical foundations of the present study, the literature is extremely useful. The topic itself is interesting and topical for researchers, who approach it from different angles.

A first innovative approach is that of the role of the Expert Knowledge Broker (EKB) in rural development. A case study was conducted in Greece and focused on Neo-Endogenous Development. In this context, an EKB is able to bring local and 'extra-local' actors together. Moreover, the EKB is able to choose the most appropriate type of rural development for a given region. The research itself was focused on the Renewable Energy projects in Greece and highlighted the need to use local and extra-local funding in order to achieve rural development [1].

Another article of research aims to assess the determinants of the development through the application of Common Agricultural Policy measures (through a case study on the spatial distribution of the rural development in Poland). The study has showed that the European Union rural development policy continues to remain far-centering and to favor regions where agricultural structures are better represented, strengthening regional disparities with rural areas with agricultural potential [2].

Rural development in China is analyzed on the basis of the concept of urban expansion, which has accelerated the phenomenon of economic and social development but has had a negative effect on the environment and social development. From 1970 to the present, there has been a regression of the rural areas in China, visible when a Cobb-Douglas type model is applied to measure the effect of urbanization on rural development using characteristics in a spatial distribution. This paper is interesting for Europe as it reflects a current global trend of increasing urbanization and reducing rural demiography amid the development of processes such as digitalization, global trade, the IoT (Internet of Things), etc. The research 
results marked the elements of the sustainable development strategy in the context of increasing urbanization and environmental degradation [3].

Sustainable rural development is the subject of an analysis with reference to Romania. The authors present a viable alternative for the economic development of rural areas and increasing the living standards of communities by strengthening rural tourism in the North West region of Romania, based on enhancing factors such as preserving traditions, landscape attractiveness, hospitality, security and the safety of tourists. The results of the study reflect the fact that there is, in the Romanian rural area, a potential for sustainable development of the tourism sector, but this potential cannot be realized without the involvement of the community [4].

The performances of local management in the rural development are analyzed in an investigative study of the relational type between their performance and the active participation of the rural communities in sustainable rural development. In this context, it is noted that social capital can become an important source for contemporary rural development, which, together with the community, can become a successful recipe (social trust in execution of socio-economic plans) [5].

A strategy to revitalize rural areas and rural development itself in China highlights that agriculture, farmers and rural areas are the pillars of the new approach in the field. A SWOT (Strengths, Weaknesses, Opportunities, and Threats) analysis of the rural areas in China highlights the fact that rural revitalization eliminates poverty, improves the quality of the environment and superiorly mobilizes the available resources to the rural environment [6].

An interesting connection between rural development and the reduction of migration flows is analyzed in a paper by some American researchers. According to them, this connection can be a help in limiting the migration phenomenon, given the differences in perceptions of the population in urban and rural areas. The authors believe that the agricultural sector and its development can be a catalyst for the migrants' absorption, giving to the economic development a sustainable status, through the development of the agricultural technologies and limiting the unskilled labor in agriculture [7].

In the current conditions of food overproduction due to increased productivity in developed countries, some authors consider that the new food supply is of lower quality, but with lower prices, and favors overconsumption in developed countries and diseases such as obesity, diabetes, etc. At the same time, malnutrition is manifesting itself in developing countries due to the global competition in food procurement. These developments are accompanied by environmental degradation and produce long-term negative effects on producers and consumers. The authors propose a refocused approach on the criteria of a productive and efficient food system, able to support health and sustainability, including through the development of rural areas [8].

Foreign investments in agriculture may be, in the opinion of other authors, a solution for rural development, especially for developing countries, countries where the access to technology is limited $[9,10]$.

International trade is a driving force for the development of agricultural areas as long as the agricultural production in these areas is efficient and competitive. In order to achieve this goal, it is necessary to identify proactive measures to shape an agricultural model based on market functionality and adaptability to global trade. The comparative analysis of Romanian agriculture's competitiveness vs the agriculture of the other Member States revealed that the concentration of trade relations in the EU (European Union) area attracts competitiveness, but also that there are Member States that have an advantage in this equation. Romania has managed to increase the competitiveness of its agricultural sector by diversifying the food processing industry, an aspect that is a premise of rural development [11].

On the other hand, agricultural farms produce non-agricultural goods and services, even in the current period. They use different inputs than those used to obtain agricultural goods, which they sell on the market, thus increasing the farmers' incomes. Finally, the 
technical and financial performance of these farms were analyzed in the case of family farms in Italy. Obtaining additional income in these farms cannot be achieved without diversifying activities and income sources. Another factor with a positive effect on farms and rural development is education [12].

The problem of association in agricultural holdings has led to the finding that there are large disparities between agricultural regions (in this case, in France) in relation to the size and the frequency of the association's forms. Moreover, contemporary conditions have supported the separation of agricultural producers into large holdings (such as Groupement Agricole d'Exploitation en Commun-GAEC) and family farms (EARLs-Exploitations Agricoles a' Responsabilite'Limite'e). Currently, GAEC owns 7.6\% of the total agricultural farms and $15 \%$ of the adult labor factor in agriculture. These different evolutions in the development of agricultural farms are largely due to historical evolution, globalization and the need to protect the environment [13].

A meta-analysis on economic behavior and the transfer of performance to agriculture has been performed by a group of authors which analyzes the correlations between the economic and the demographic phenomena, the technological characteristics and the size of the development over time of agriculture and economic behavior. Moreover, they seek to identify future research topics in the field in order to assist the agricultural policy makers and stakeholders in developing a sustainable strategy for rural development [14]. The need to plan and modernize the associative model is addressed in a paper regarding Greek agriculture. The author identifies the small Greek farmer as a small entrepreneur who tries to survive in the economic environment through specific forms of cooperation and rural association. This demonstrates that these associative forms represent a solution for rural development in other countries, as well [15].

The research of specialized literature reflects the fact that rural development is closely related to the agricultural producer. The interaction of this producer with economic flows and the social and environmental factors represent aspects that are the object of the sustainable development policies and that generate ample strategic development programs in this field. In this context, the efficiency of the associative forms becomes a challenge because they can represent the fruition of a comparative advantage (accumulation of resources), but at the same time they can be real sources of misunderstandings or economic dissensions that curb the beneficial potential of these associations. In the absence of coherent policies, the vulnerabilities tend to outweigh the benefits, and rural development suffers.

These aspects motivate the delimitation of the role of the associative forms in the concrete conditions of the organizational standards in Romania [16], which often demonstrates a quantified specificity in terms of cultural and economic baggage of the organization, which makes its mark on the economic result of the associative forms: rural development.

In the view of [17], regional development of agriculture represents critical points in the overall stability of population welfare. This is also reflected by the growing demand for food and fiber. The author point out that, in the context of a dynamic climate and demographic and economic changes, ensuring the agricultural sector's sustainability is a key factor for socio-economic stability. The author proposes some directions for action based on strengthening the commercial capacity of agricultural farms by providing infrastructure, increasing the efficiency and effectiveness of the agricultural bodies through Research\& Development (R\&D), improved management models in agriculture and addressing trade barriers in a favorable way to these entities (product traceability). This model confirms that government policies are a supporting factor that can mitigate the risk to associative forms in order to ensure a sustainable balance in regional agricultural markets.

The correlation between sustainable agricultural development, profit and uncertainty is studied in the case of cereal production using a dynamic model developed by [18]. The model provides scenario-based optimization of production estimated up to 2030 (triangular distribution between costs, prices and quantities obtained per year over the period 20252030). Although we have reservations about forecasting profit histograms with uncertainty, we consider the idea of evaluation based on five scenarios useful for estimating the regional 
capacity for productive expansion through strategic agricultural production planning. Thus, the prerequisites for strengthening the administrative capacity of the associative forms in agriculture are achieved.

A theoretical approach, based on the econometric modeling of dynamic correlations of randomized impact factors assimilated to agricultural development, is carried out by [19] in a scientific study assessing the behavioral paternity of agricultural development in Ukraine during 1996-2018. The results of the study show that this approach allows forecasting the decline in the economic growth of the agricultural sector according to the separate evolution of influence factors so that peaks of growth and periods of economic recession in the agricultural sector can be predicted.

In order to assess the impact of agriculture on the development of the regional economy, input-output analysis was applied in a study carried out by [20]. Furthermore, the authors developed a regional model capable of quantifying the contribution of the primary sector to the regional economy as well as the contribution of the Common Agricultural Policy to the development of the local economy. The results of this research point out that agriculture is an important factor of regional development and it is able to support the increase of the local gross output.

In a study on the Russian economy, the small and medium-sized associative agricultural forms are deprived as regional entities that benefit from the ability to associate in a small area, with limited capacity and little stability from external influence. In times of crisis, these organizations can be easily destabilized in the absence of innovative development directions [21], which consist, according to [22], of improving the fiscal climate and the input supply system and the introduction of a new taxation system for these operators. Given the national size of the agricultural associations, the opportunity to adopt such a package of measures is high.

Two important articles in clarifying the issues of the production value forecasting as a factor in the sustainable development of the agricultural sector are realized by [23] and [24]. In an impact study, the authors demonstrate that the SARIMA model (Seasonal Autoregressive Integrated Moving Average) can be used in relation to factors such as access to the transport network, import and export volumes of products, logistical redistribution of cargo, changes in agricultural policy, changes in consumer demand to identify price saturations and forecasting production volumes in a sustainable manner.

The development of agriculture from another topical perspective takes into account the information systems according to the land configuration. The authors show that the systematization of production by bringing non-productive land into the productive circuit, part of the extensive development component, can be achieved through CIM (Computation Independent Model) and MDA (Model Driven Architecture) models in a sustainable way which technically supports the agricultural management decisions and repositions the development strategy in line with the reality on the ground $[25,26]$. We consider this approach to be complementary to the forecasting model presented earlier [23], and consider that it can contribute to increasing the sustainability of agricultural sector development by combining the two methods. This was also considered in our present study.

Following a rigorous meta-analysis, it was concluded that the exchange of best practices in agriculture is not topical because the production conditions, climatic conditions and logistical facilities vary significantly from a regional point of view, so that common practices represent an aspect that must at least be adapted to by deepening the knowledge of the influencing factors that determine sustainability in integrated farm management [27].

A new approach to sustainable agricultural development strategy takes into account aspects of cooperation between the agricultural entities operating in the agricultural microenvironment as well as in the economic macro-environment [28]. The authors show that the success of the associative forms depends both on the organization and management of the associations, on the individual characteristics of the associating entities and on external conditions, market factors, agricultural policies and other macroeconomic characteristics in 
such a way as to ensure that social, environmental and economic criteria are met, in turn ensuring the sustainability of the association and the acceptance of collaboration.

Considering the complexity of the issue of associative forms, the areas of development and the potential that this branch has as a support for national and regional economies, we adapted our approach to carry out an impact study on associative forms and their ability to contribute, in a sustainable way, to economic well-being as being timely and necessary. This approach is intended to clarify, on the basis of feedback from managers of associative forms, aspects that will vitalize the regional and national strategy to boost this economic branch.

\section{Methodological Approach}

The present study was conducted on the basis of a questionnaire applied to 233 agricultural cooperatives during June 2020-March 2021, throughout Romania, obtaining a representation of over $95 \%$ of the sample at the level of such entities in Romania. It validates the information collected through the questionnaire as a reference point in drawing development models based on the connection to the associative capacity of the agricultural producers in Romania.

The procedure for obtaining responses from the questionnaire went through the following steps:

- contacting potential respondents by e-mail and informing them about the purpose and objectives of the research;

- Google forms design of the questionnaire;

- $\quad$ sending the questionnaire to the entities in the target group, i.e., agricultural holding companies in Romania;

- collecting data and re-contacting non-respondents by e-mail in order to obtain information by their completion of the questionnaire;

- $\quad$ statistical consolidation of the data;

- use of data for modelling.

The procedure was used in a pandemic context, which did not allow physical contact but only contact by e-mail or telephone.

The structured questionnaire aimed at identifying the characteristics of the associative forms (the sector of activity in which it mainly carries out its activity, the level of education and training of the association's members and the age of the association's members). The second section was represented by the evaluation of the economic dimension of the activity, the respondents being asked questions regarding the turnover, the supply structure and the sales processes and the detailing of the market shares depending on the level of market coverage. Another question in this section was on access to finance. The third section of the questionnaire was represented by the connection with the rural development dimension both as a provider of stability and as a beneficiary of the impact measures promoted by the authorities, which should benefit the associative forms (see Table 1).

Table 1. The questionnaire map.

\begin{tabular}{|c|c|c|c|c|c|c|c|}
\hline Question & $\begin{array}{l}\text { Answer's } \\
\text { Options }\end{array}$ & Symbol & $\begin{array}{c}\% \text { of } \\
\text { Representativity } \\
\text { in Total } \\
\text { Responses }\end{array}$ & Question & Answer's Options & Symbol & $\begin{array}{c}\% \text { of } \\
\text { Representativity } \\
\text { in Total } \\
\text { Responses }\end{array}$ \\
\hline \multirow{5}{*}{ Activity } & Production & AGQ & $54.74 \%$ & \multirow{5}{*}{$\begin{array}{l}\text { The top of the } \\
\text { governmental } \\
\text { policies }\end{array}$} & Incentives & GPI & $77.59 \%$ \\
\hline & $\begin{array}{l}\text { Agricultural } \\
\text { production } \\
\text { processing }\end{array}$ & AGPRO & $10.34 \%$ & & Microfinancing & GPM & $68.53 \%$ \\
\hline & Trading & AGTR & $30.17 \%$ & & Development & GPD & $53.45 \%$ \\
\hline & Services & AGS & $1.72 \%$ & & Support & GPS & $40.95 \%$ \\
\hline & Others & AGO & $3.02 \%$ & & Base & GPB & $21.12 \%$ \\
\hline
\end{tabular}


Table 1. Cont.

\begin{tabular}{|c|c|c|c|c|c|c|c|}
\hline Question & $\begin{array}{l}\text { Answer's } \\
\text { Options }\end{array}$ & Symbol & $\begin{array}{c}\% \text { of } \\
\text { Representativity } \\
\text { in Total } \\
\text { Responses }\end{array}$ & Question & Answer's Options & Symbol & $\begin{array}{c}\% \text { of } \\
\text { Representativity } \\
\text { in Total } \\
\text { Responses }\end{array}$ \\
\hline \multirow{5}{*}{$\begin{array}{l}\text { Education \& } \\
\text { training }\end{array}$} & $\begin{array}{l}\text { Without } \\
\text { education }\end{array}$ & EDWE & $1.92 \%$ & \multirow{6}{*}{$\begin{array}{l}\text { Holdings' } \\
\text { promoting }\end{array}$} & $\begin{array}{l}\text { Contribution to the } \\
\text { food security }\end{array}$ & HPFS & $50.43 \%$ \\
\hline & Basic & EDB & $15.80 \%$ & & $\begin{array}{l}\text { Improving the } \\
\text { farmer's role on the } \\
\text { agricultural and food } \\
\text { chain }\end{array}$ & HPF & $86.64 \%$ \\
\hline & College & EDC & $42.60 \%$ & & Decreasing poverty & HPDP & $30.17 \%$ \\
\hline & University & EDUN & $35.41 \%$ & & New jobs generating & HPNJ & $43.53 \%$ \\
\hline & $\begin{array}{c}\text { Post- } \\
\text { University }\end{array}$ & EDPU & $4.27 \%$ & & Financial services & HPFS & $27.59 \%$ \\
\hline \multirow{5}{*}{ Age (years) } & $21-30$ & AGEY & $10.47 \%$ & & $\begin{array}{c}\text { Socio-Economic } \\
\text { development }\end{array}$ & HPSCD & $45.69 \%$ \\
\hline & $31-40$ & AGEAV & $23.60 \%$ & \multirow{3}{*}{$\begin{array}{l}\text { Opportunities } \\
\text { in promoting } \\
\text { agricultural } \\
\text { holdings }\end{array}$} & No & OPAH & $0.86 \%$ \\
\hline & $41-50$ & AGEAC & $34.47 \%$ & & Yes & & $71.98 \%$ \\
\hline & $51-60$ & AGEAD & $20.11 \%$ & & No opinion & & $27.16 \%$ \\
\hline & $>60$ & AGEO & $11.36 \%$ & \multirow{7}{*}{$\begin{array}{l}\text { Measures } \\
\text { regarding the } \\
\text { rural } \\
\text { development }\end{array}$} & $\begin{array}{l}\text { Strategical joint with } \\
\text { the public authorities }\end{array}$ & RDSJ & $23.71 \%$ \\
\hline \multirow{4}{*}{$\begin{array}{l}\text { Turnover } \\
\text { (euros) }\end{array}$} & $1:<10,000$ & TUVL & $60.34 \%$ & & $\begin{array}{l}\text { Promoting the } \\
\text { benefits and costs of } \\
\text { the association }\end{array}$ & RDBC & $32.33 \%$ \\
\hline & $\begin{array}{c}2: \\
10,000-100,000\end{array}$ & TUL & $12.07 \%$ & & $\begin{array}{l}\text { Incentives, including } \\
\text { financial measures }\end{array}$ & RDI & $25.43 \%$ \\
\hline & $\begin{array}{l}\text { 3: } 100,000- \\
1,000,000\end{array}$ & TUM & $15.52 \%$ & & Rural development & RDRD & $41.38 \%$ \\
\hline & $4:>1,000,000$ & TUH & $12.07 \%$ & & Regional partnership & RDRP & $33.19 \%$ \\
\hline \multirow[t]{2}{*}{ Inputs } & Producer & IP & $34.61 \%$ & & $\begin{array}{l}\text { Shorting the logistic } \\
\text { chains }\end{array}$ & RDLC & $18.97 \%$ \\
\hline & Distributor & ID & $65.39 \%$ & & No opinion & RDNO & $33.62 \%$ \\
\hline \multirow{7}{*}{ Goods market } & $\begin{array}{l}\text { Domestic } \\
\text { market }\end{array}$ & DM & $45.16 \%$ & \multirow{8}{*}{$\begin{array}{l}\text { The public } \\
\text { intervention in } \\
\text { supporting the } \\
\text { rural } \\
\text { development }\end{array}$} & $\begin{array}{l}\text { Promoting } \\
\text { transparency and } \\
\text { trasability for the } \\
\text { agricultural job }\end{array}$ & PITT & $27.59 \%$ \\
\hline & $\begin{array}{l}\text { External } \\
\text { market }\end{array}$ & EM & $4.00 \%$ & & $\begin{array}{c}\text { Concrete economic } \\
\text { incentives }\end{array}$ & PICI & $25.86 \%$ \\
\hline & $\begin{array}{l}\text { Domestic } \\
\text { traders }\end{array}$ & DT & $24.63 \%$ & & $\begin{array}{l}\text { Financial support } \\
\text { and fiscal facilities }\end{array}$ & PIFS & $55.17 \%$ \\
\hline & $\begin{array}{l}\text { Domestic } \\
\text { processors }\end{array}$ & DP & $12.23 \%$ & & $\begin{array}{l}\text { Viable regional } \\
\text { development } \\
\text { programmes }\end{array}$ & PIRP & $21.55 \%$ \\
\hline & $\begin{array}{l}\text { Domestic } \\
\text { consumers }\end{array}$ & $\mathrm{DC}$ & $8.75 \%$ & & $\begin{array}{l}\text { Strategical } \\
\text { partnership }\end{array}$ & PISP & $21.55 \%$ \\
\hline & Export EU & EEU & $4.90 \%$ & & $\begin{array}{l}\text { Developing coherent } \\
\text { agricultural policies }\end{array}$ & PIAP & $19.40 \%$ \\
\hline & Export non-EU & ENEU & $0.33 \%$ & & $\begin{array}{l}\text { Improving the law } \\
\text { approach }\end{array}$ & PILA & $25.00 \%$ \\
\hline $\begin{array}{l}\text { Access to } \\
\text { financing }\end{array}$ & Yes & $\mathrm{AF}$ & $42.24 \%$ & & $\begin{array}{c}\text { Particular measures } \\
\text { for rural } \\
\text { development }\end{array}$ & PIRD & $30.60 \%$ \\
\hline
\end{tabular}

These three sections allowed a complete radiography of the associative forms in Romania, radiography that highlights at the structure level the fact that: 
- most associative forms have concerns in the agricultural productive sector; there are some entities concerned with services or trade;

- the level of education is mainly secondary and higher education, which means that, through entrepreneurship and rural development programs carried out at governmental or European level, it has been possible to attract young people with specialized training in the agricultural sector, which is an advantage for rural development;

- from the age structure of the sample point of view, the respondents are mainly aged between 41-50 years, with a homogeneous left-right distribution around the median interval, respectively, on the age levels of 31-40 and 51-60 years. This represents the fact that most of the respondents are part of the adult population, the young labor force being less attracted by the agricultural sector. This is a long-term disadvantage for rural development;

- the evaluation of the economic dimension generated results at the level of the sample, as follows: the median range of the turnover is located at the level of the annual economic performance of up to 100,000 euros / associative form, which is a disadvantage for rural development in the sense that most economic agents fail to obtain superior yields, which would allow them a sustainable economic growth and which would effectively contribute through the four functions (economic, social, contributions to the public system, and environment) to rural development. This aspect generates the need to improve the efficiency conditions through several policies and actions to support the associative forms;

- from the use of internal resources or imported resources for the activity point of view, it is found that the share of purchases from distributors (imports or retailers) is double the share of use of domestic resources, which contributes to the balance of payments deficit and slows rural economic development;

- regarding the sales market, the analysis based on the questionnaire highlighted the fact that the sales market of the associative forms is mainly the internal market, on the retail component. A share of $5 \%$ is destined for exports, most of which targets the European Union market. Other production destinations are to processors $(18.2 \%)$ and direct consumers $(13.7 \%)$. This structure of the sales markets does not favor rural economic development, because the exports' limitation intrinsically slows down this development;

- a share of $42 \%$ of the associative forms declared the fact that they benefited during the financing time through European projects or national programs, which presents a quite good percentage in terms of accessing funds and adhering to the financing programs;

- the analysis of the third part of the questionnaire highlighted the fact that at the level of associative forms the need for the governmental support measures and policies is known and realized. The majority of respondents (78\%) state that they feel the need for incentive policies regarding specific activities, policies that should be coordinated at the governmental level. Secondly, the need for microfinance is perceived at the level of $70 \%$ of the sample, an aspect that completes the reduced efficiency of the economic activity expressed by the average turnover of up to 100,000 euros achieved at the level of the sample. At the same time, over $50 \%$ of the respondents stated that government policies should be oriented towards the development of the agricultural branch, and $40 \%$ towards the support of activity through government policies;

- $\quad$ regarding the promotion of agricultural holding companies, promotion actions would aim, in the opinion of the majority of respondents (87\%), to consolidate the role of the farmer within the agricultural and food chain. A total of $50 \%$ of the respondents appreciate that promotion of holding companies would contribute to ensuring food security, socio-economic development and job creation. Poverty reduction and access to accessible financial services represent promotional outputs in the opinion of only $30 \%$ of respondents; 
- over $70 \%$ of respondents consider promotion as a viable opportunity for economic recovery. In terms of rural development impact measures, over $40 \%$ of the respondents believe that effective rural development measures would influence the proper functioning of holding companies, while over $30 \%$ believe that promoting the benefits and obligations of the association or regional cooperation is a way of increasing economic development efficiency. Only $25 \%$ of the respondents appreciate strategic cooperation with the authorities or concrete incentive measures as alternatives to economic development. In addition it resulted through the questionnaire that economic operations performed within the existing logistics chain are optimally represented ( $80 \%$ of respondents), while the reduction of the logistics chain is agreed by $20 \%$ of respondents. Regarding the ways of state intervention in supporting rural development, the majority of respondents (over $50 \%$ ) opt for financial support and the provision of fiscal facilities. This aspect does not contribute on the long term to sustainable rural economic development because the dependence on funds is an element of economic regression in any field, especially in the agricultural field. The second measures regarding state intervention in supporting rural development are the specific measures adopted in the field, and lower weights aim at strengthening legislative framework, adopting viable regional development programs, strategic cooperation, developing coherent agricultural policies or promoting transparency and traceability of the profession.

Considering the above and the study of literature, we define the following working hypotheses for the conceptualization of the rural economic development model regarding the economic efficiency of associative forms in the agricultural sector of Romania:

H1. The specific measures of rural development represent an effective approach to the state intervention in supporting local economic development if and only if they offer concrete measures of economic stimulation for at least $40 \%$ of the economic agents / associative forms in the region;

H2. The adoption of specific measures of rural development becomes efficient if the regional development programs are accessed by at least 50\% of the economic agents/associative forms in the region and has as the effect of development of coherent agricultural policies, with an effect on the turnover of the holding companies.

H3. The specific measures for rural development are all more effective as the provision of financial support and fiscal facility is better regulated.

H4. Regional cooperation is an element of vulnerability in the current context and must be maximized through specific government programs.

Consolidation processes of the databases resulting from the collection of the answers from the questionnaire were used through XL (Microsoft Excel) and SPSS (Statistical Product and Service Solutions) software. A procedure of quantitative quantification of qualitative data and data standardization procedures was applied, thus resulting in a model-able database with over 11500 records. The data were modeled using the least squares method and linear regression, using as a dependent variable specific measures of rural development (noted as PIRD) and the impact measures on rural development (noted as RDRD) in relation to the regressors:

- Measures of impact on rural development (strategic cooperation with the authoritiesRDSJ; promoting the association's benefits and obligations-RDBC; concrete incentive measures, including financial-RDI; regional cooperation-RDRP; reducing the logistics chain-RDLC; alternative impact measures-RDNO);

- Ways of state intervention in supporting the rural development (promoting the transparency and traceability of the profession-PITT; concrete measures of economic stimulation-PICI; financial support and provision of fiscal facilities-PIFS; viable regional development programs-PIRP; strategic cooperation-PISP; developing coherent agricultural policies-PIAP; strengthening the legislative framework-PILA). 
The modelling results (obtained by applying the linear regression function) of the evaluation with the Enter method allowed the introduction of all regressors in the equation, the estimated model being adequate according to a coefficient of determination of $82 \%$ for a Durbin-Watson test that tends to 2 and a degree of freedom of the regression variables of 14 out of a total of 231 degrees of freedom.

The model equation is of the form:

$$
V d=\sum_{i=1}^{15} \alpha_{i} r_{i}+\varepsilon
$$

The dependent variable $(\mathrm{Vd})$ represents the possibility of implementing impact measures on the rural development (RDRD) in the opinion of the interviewed holdings, the logical variable with two response steps for the possibility and impossibility of adopting impact measures.

$\varepsilon$ represents the residual value left after the design of the regression equation, in our case being assimilated to a sum of the residual squares from the total sum of the squares of $16 \%$ or to 217 degrees of freedom from the total of the 231.

The regressive variables $\left(r_{i}\right)$ represent the rural development modalities through the state intervention in supporting rural development, respectively:

- $\quad$ strengthening the legislative framework-PILA;

- financial support and granting of fiscal facilities-PIFS;

- $\quad$ alternative impact measures -RDNO;

- regional cooperation-RDRP;

- $\quad$ promoting the association's benefits and obligations-RDBC;

- concrete incentive measures, including financial ones-RDI;

- opportunities to promote holding companies-OPAH;

- concrete measures of economic stimulation-PICI;

- $\quad$ strategic cooperation with the authorities-RDSJ;

- $\quad$ promoting the profession's transparency and traceability-PITT;

- $\quad$ strategic cooperation-PISP;

- viable regional development programs-PIRP;

- development of coherent agricultural policies-PIAP;

- reduction of the logistics chain-RDLC.

The coefficients of the regression variables $\left(\alpha_{i}\right)$ are determined based on Pearson correlation, their value being determined by the non-standardized value $(\beta)$ in the table of coefficients, a value that is presented below and which reflects direct or indirect proportionality with the dependent variable. All of the above reflects a homogeneous distribution of the model for a coefficient of determination of $82 \%$ and a standard estimator error of 0.2. The Sig value of the F test tends to 0 , which proves that the model is valid and representative for the studied phenomenon. The data are presented in Table 2.

Table 2. Model Summary ${ }^{\mathrm{b}}$.

\begin{tabular}{|c|c|c|c|c|c|c|c|c|c|c|}
\hline \multirow[b]{2}{*}{ Model } & \multirow[b]{2}{*}{$\mathbf{R}$} & \multirow[b]{2}{*}{ R Square } & \multirow{2}{*}{$\begin{array}{l}\text { Adjusted } \\
\text { R Square }\end{array}$} & \multirow[b]{2}{*}{$\begin{array}{l}\text { Std. Error of the } \\
\text { Estimate }\end{array}$} & \multicolumn{6}{|c|}{ Change Statistics } \\
\hline & & & & & $\begin{array}{l}\text { R Square } \\
\text { Change }\end{array}$ & F Change & df1 & df 2 & $\begin{array}{l}\text { Sig. F } \\
\text { Change }\end{array}$ & $\begin{array}{l}\text { Durbin- } \\
\text { Watson }\end{array}$ \\
\hline 1 & $0.913^{\mathrm{a}}$ & 0.834 & 0.823 & 0.208 & 0.834 & 77.695 & 14 & 217 & 0.000 & 2.202 \\
\hline
\end{tabular}

The histogram distribution performed by the residual normality test reflects homogeneity under the Gaussian curve, with the accumulation on the ascending slope near the maximum of the median interval (see Figure 1). 


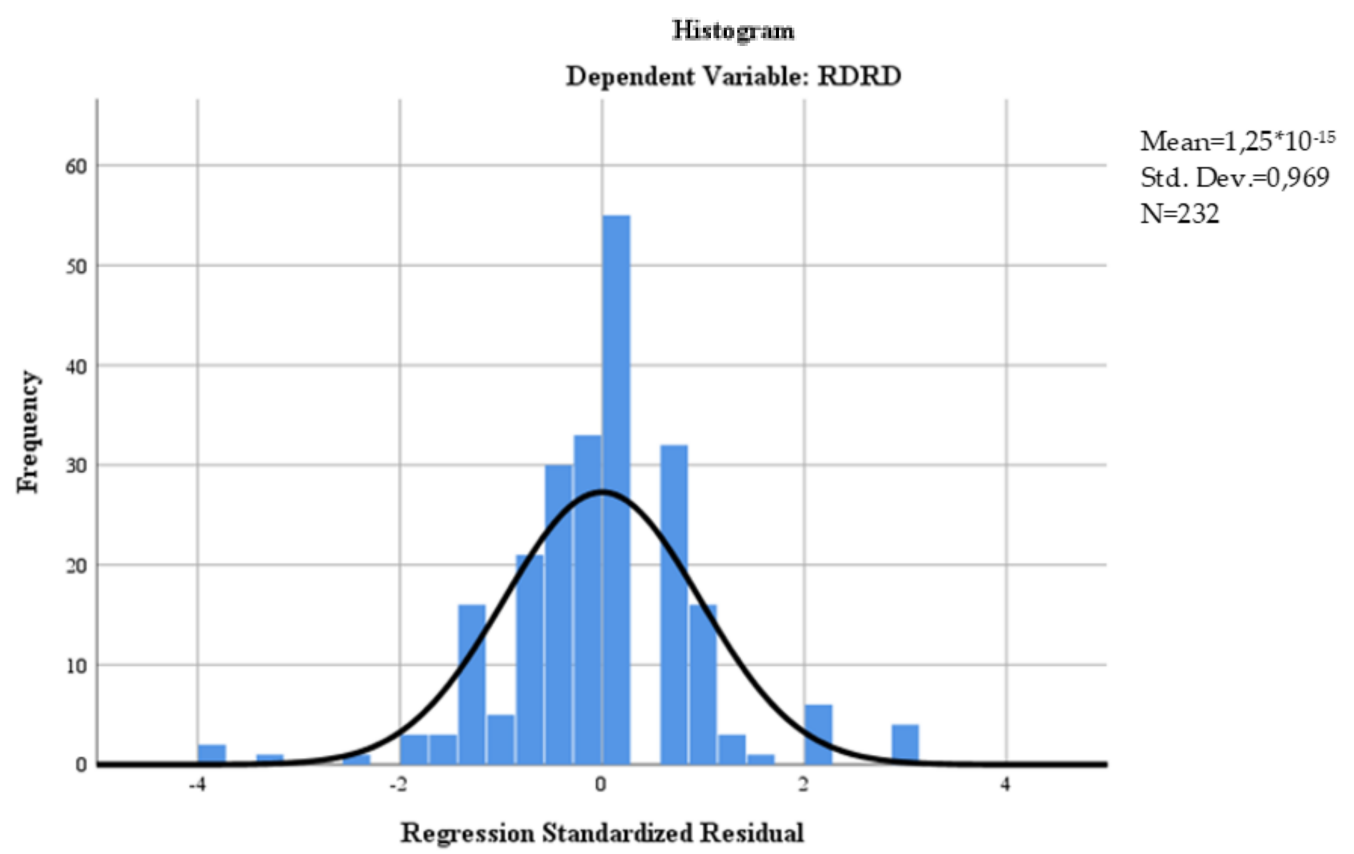

Figure 1. Histogram distribution for RDRD.

According to the P-P Plot distribution for the trend line forecast in relation to the observational values, it results that the biggest variations are found in the cases of 3- trade and 1-production, sectors that experience the biggest dynamics at the level of Romanian agriculture. These sectors attract the highest turnover, which explains the distribution of the P-P Plot (Figure 2).

Normal P-P Plot of Regression Standardized Residual

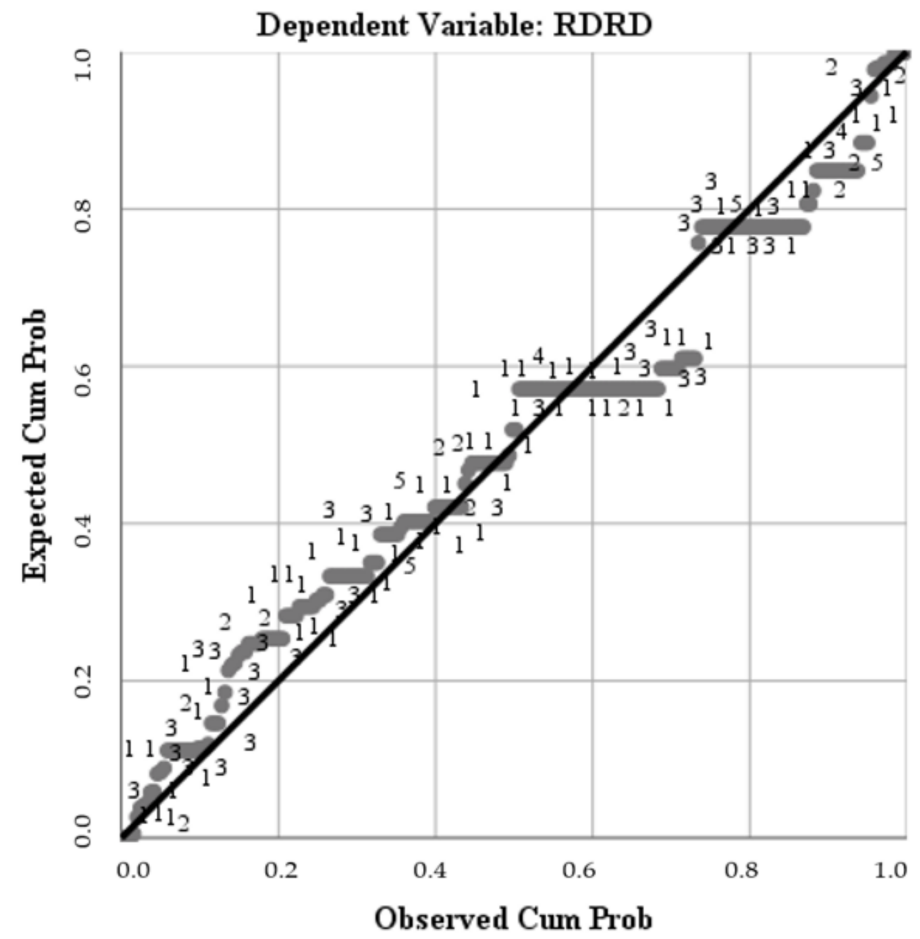

Figure 2. P-P Plot distribution for RDRD. 
The ANOVA test confirms the statistical results of the model by the relatively small percentage of the sum of the residual squares (16\%) of the total, the small number of degrees of freedom of the regression variables (14) and the value Sig $\rightarrow 0$ for Test F (see Table 3).

Table 3. ANOVA Test for RDRD.

\begin{tabular}{|c|c|c|c|c|c|c|}
\hline \multicolumn{7}{|c|}{ ANOVA $^{a}$} \\
\hline & Model & Sum of Squares & df & Mean Square & $\mathbf{F}$ & Sig. \\
\hline \multirow{3}{*}{1} & Regression & 46.916 & 14 & 3.351 & 77.695 & $0.000^{\mathrm{b}}$ \\
\hline & Residual & 9.360 & 217 & 0.043 & & \\
\hline & Total & 56.276 & 231 & & & \\
\hline \multicolumn{7}{|c|}{$\begin{array}{c}\text { a. Dependent Variable: RDRD } \\
\text { b. Predictors: (Constant), PILA, PIFS, RDNO, RDRP, RDBC, RDI, OPAH, PICI, RDSJ, PITT, PISP, } \\
\text { PIRP, PIAP, RDLC }\end{array}$} \\
\hline
\end{tabular}

The proposed model is valid and quantifies the poor development of the associative forms in the Romanian agriculture based on the elements of associative history and inconsistency of the regulatory framework. These aspects affect the rural economy through the qualitative component of the cooperation and cohesion policies, but also through the quantitative dimension, according to which the access to financing is only used in some cases in representative financial indicators such as turnover or profit.

The development measures, as a result of modelling, must be based mainly on the components whose correlation with rural development is in direct proportionality and of high statistical significance. The rest of the components represent the vulnerabilities that hinder the economic potential of these associative forms in reaching their maximizing function and represent significant impact factors on rural development.

\section{Results and Discussion}

The report for the purpose of this study revealed that, although the concept of associations could have beneficial effects on the holdings and rural development as a whole, there are several vulnerabilities (deduced by calculating the regression of the independent variables from the dependent variable) able to affect the holding companies' efficiency in Romania and to represent punctual realities and not a system reality at this time.

In this sense, we consider opportune the analysis of the regression coefficients in parallel with the partial diagrams represented on the coordinated system with the dependent variable as residual standardized diagrams.

The first regression coefficient assigned to the variable (strengthening the legislative framework-PILA) has the value of 0.575 . The coefficient indicates a significant correlation between the effective ways of the rural development and the strengthening of the legislative framework, respectively, that the measure will generate a superior effect at the level of rural development. It is found that the distribution of partial regression is bipolar (2 clusters), which means that there is different legislative adaptability for the entities in the same economic sector marked on the graph with 1 for productive agricultural entities, with 2 for entities with agricultural products processing activities, 3 for the entities active on the segment of commercialization of agricultural products, 4 for service entities in the agricultural field and 5 for other entities.

Thus, there is bipolarity in sectors 1,2 and 3, the services sector being less reflective in relation to the legislative changes. This adaptability is a characteristic attributed to the entropy for the associative forms and represents an indicator of vulnerability correction, implying at the same time active measures regarding counseling, coordination, cooperation and transparency (see Figure 3). 


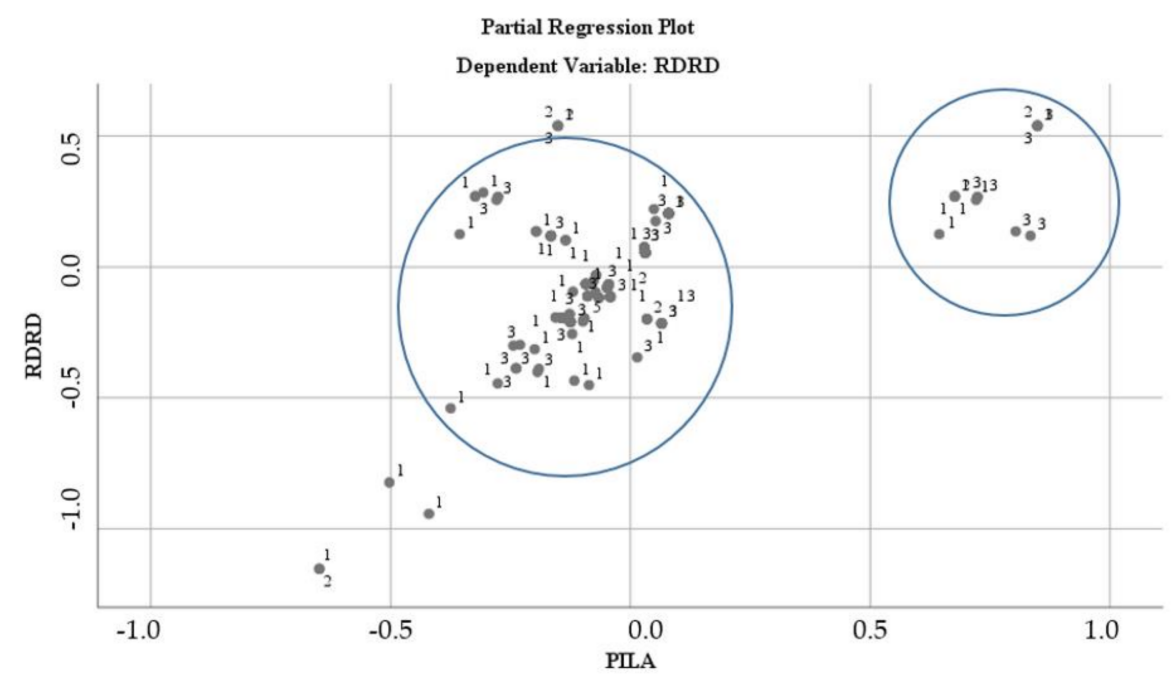

Figure 3. Regression analysis for PILA.

The second coefficient attributed to variable financial support and fiscal facilitiesPIFS, has a value of 0.467 and represents an average correlation between the effective ways of rural development and the financial support and fiscal facilitation, which means that there are vulnerabilities both in the structuring programs of financing as well as in their fructification by the beneficiaries of the financing. This demonstrates that strengthening the regional capacity of the agricultural structures can generate an improvement as notes [2]. The partial diagram reflects a linear trend without polarization but with significant distances from the trend line. The largest deviations from the trend line are found in the case of the entities in the fields of marketing and processing of food products, which means that these entities do not automatically benefit from the given support to producers or service providers (e.g., management companies, water and irrigation). As a result, these segments turn into segments more exposed to the market risk, which strengthens the systemic vulnerabilities and slows down rural development. These aspects motivate the $\mathrm{H} 2$ and $\mathrm{H} 3$ hypotheses of the research, as follows:

H2. The adoption of specific measures of rural development becomes efficient if the regional development programs are accessed by at least $50 \%$ of the economic agents / associative forms in the region and has an effect the development of coherent agricultural policies with effect on the turnover of the holding companies.

H3. The specific measures for rural development are all more effective as the provision of financial support and fiscal facility is better regulated (see Figure 4).

As some authors [22] have presented as part of the package of revitalization measures, fiscal policy can ensure the improvement of the conditions of association and increase the life span of these associative forms, along with improving their economic efficiency.

Another indicator represented by the alternative impact measures-DRNO was introduced in the modelling as an independent variable, and the non-standardized coefficient $\beta$ resulting from the modelling is -0.588 . As a result, the alternative measures have a significant indirect correlation with the dependent variable, motivated by the fact that they are by definition antagonistic. The same bipolar trend is noticeable, which for the first three categories of economic agents (production, processing, marketing) reflects the fact that the associative forms fail to maximize the development function in the current context. As such, alternative rural development measures are needed. This approach is in line with objective 1 of the research: O1: Determining the result elements regarding the efficiency of associative forms, which contribute intrinsically to rural development in Romania. According to this objective, the analysis reveals that the agricultural associative forms, through their development, are not able to ensure overall rural development today, alternative measures being necessary (see Figure 5). 


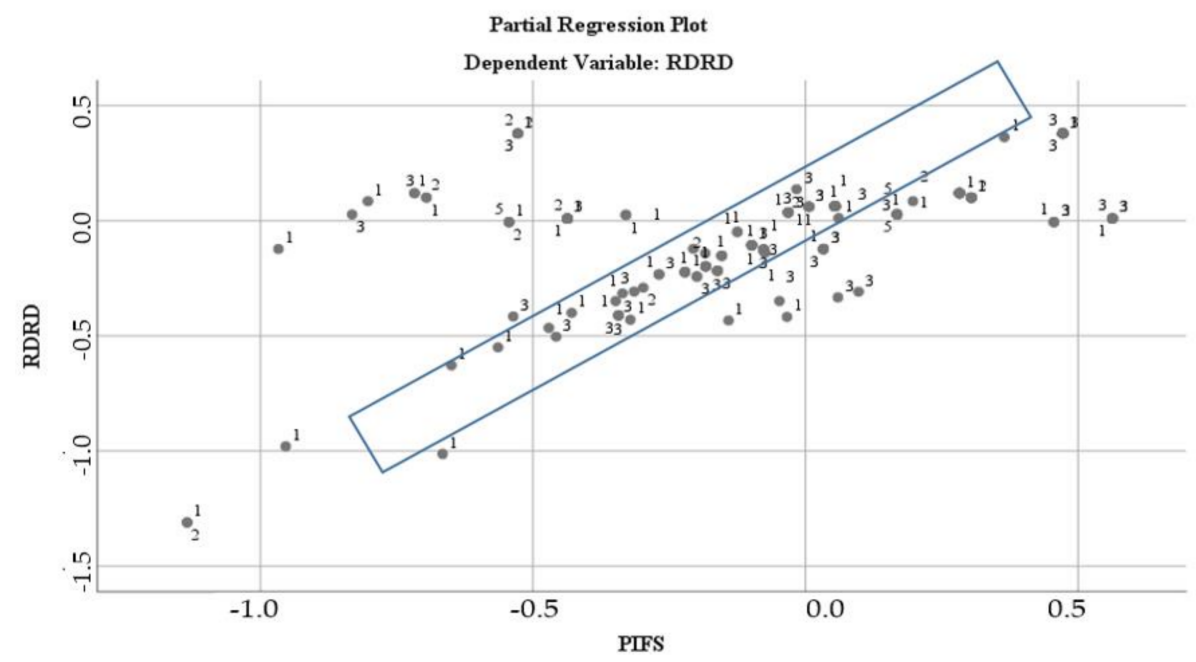

Figure 4. Regression analysis for PIFS.

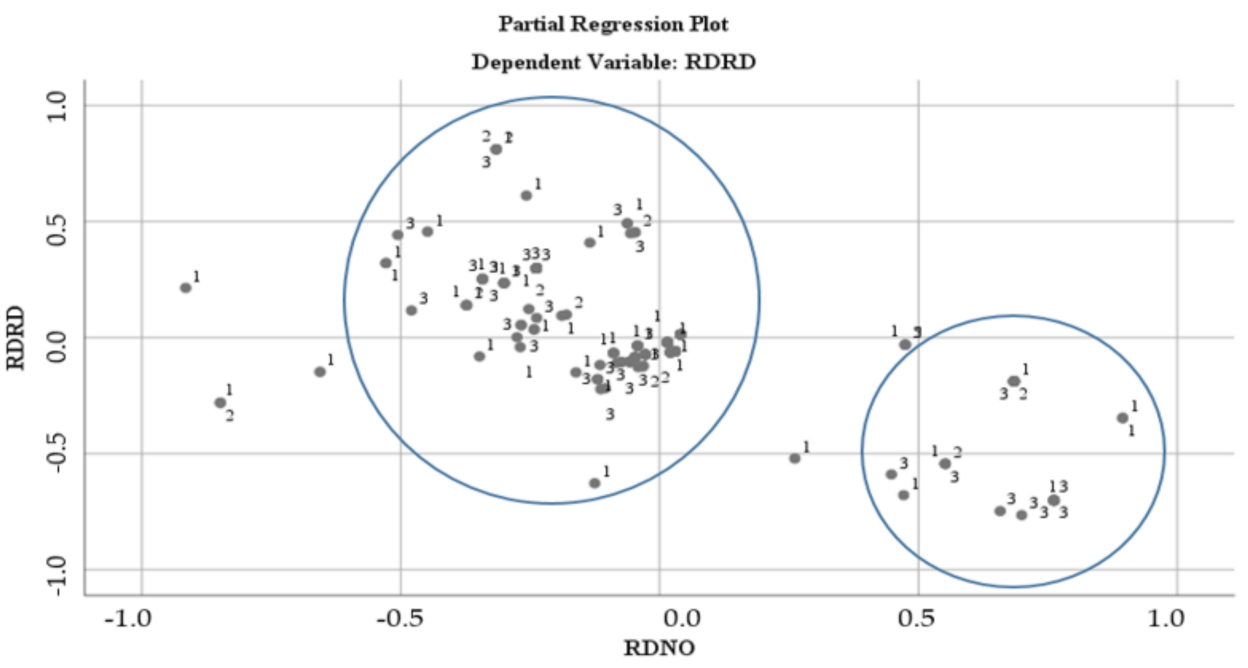

Figure 5. Regression analysis for RDNO.

A controversial output of the analysis is the regional cooperation-RDRP, a variable whose value is negative $(-0.800)$. It highlights a strong indirect correlation regarding regional cooperation, which is motivated by the poor perception of the advantages of cooperation and the recent history of this type of cooperation much of which have ended with disputes and bankruptcies of the holding companies. Our proposed study is based on the premise that the redirection of development efforts should be undertaken after identifying vulnerabilities, so that government programs can achieve maximum results with minimum effort [19]. On the other hand, strengthening the management capacity of agricultural holdings, in addition to the representative aspects of vulnerability reduction, brings a viable addition to the sustainable development. This is likely to economically strengthen the region and generate on the medium and long term an advantageous repositioning of the market shares in favor of the agricultural holding companies $[4,5,7,14,15,17,18,24]$.

According to the partial diagram, there is a reverse evolution trend (with impact on the first three forms: production, processing and marketing), an aspect that reflects the vulnerabilities assumed by objective 3 of the research: Identification of vulnerabilities that affect the function of maximizing the development of holdings on rural development, and motivating H4, as follows: H4: The regional cooperation is an element of vulnerability in the current context and must be maximized through specific government programs (see Figure 6). 


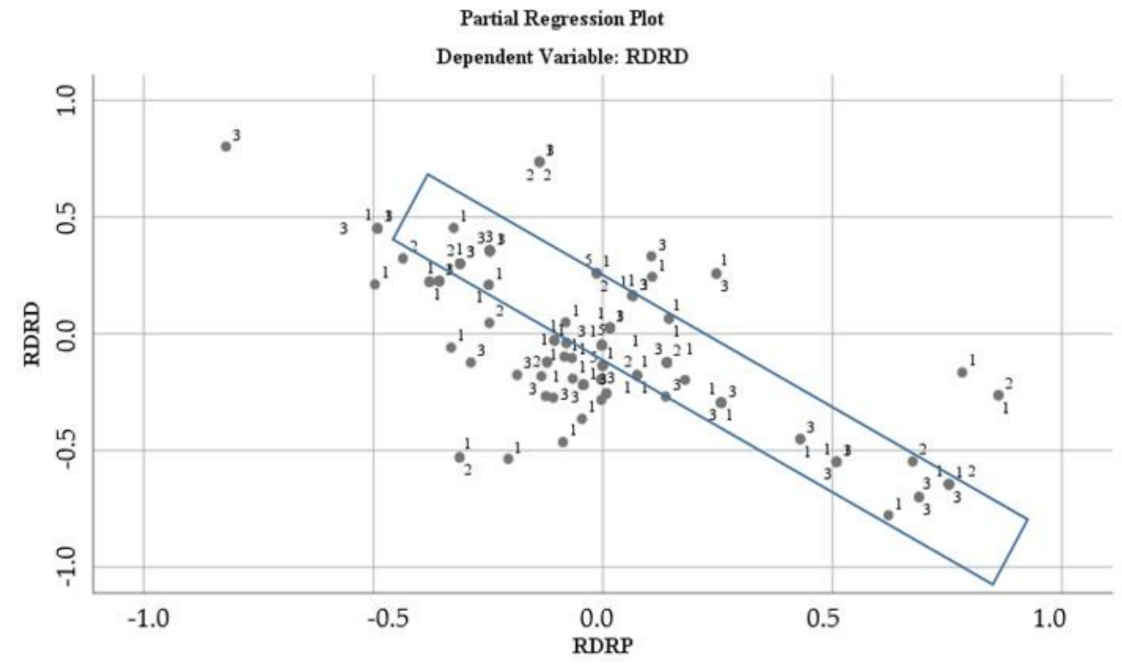

Figure 6. Regression analysis for RDRP.

This indicator, the promotion of the benefits and obligations of the association-RDBC, represents an intrinsic measure of the holding development. The $\beta$ value of the nonstandardized coefficient of the indicator is negative $(-0.830)$ and indicates a strong indirect correlation in terms of promoting the benefits and obligations of the association in the case of rural development impact measures. Under these conditions, objective 2 of the research is achieved: O2: Evaluating the efficiency of these elements by conceptualizing an econometric model of correlation regarding the holding efficiency and rural development. It reflects a minimization of the efficiency function of the existing holding companies in the current socio-economic and legislative context, which demotivates rural development, an aspect also indicated by the negative value of the regression coefficient (see Figure 7).

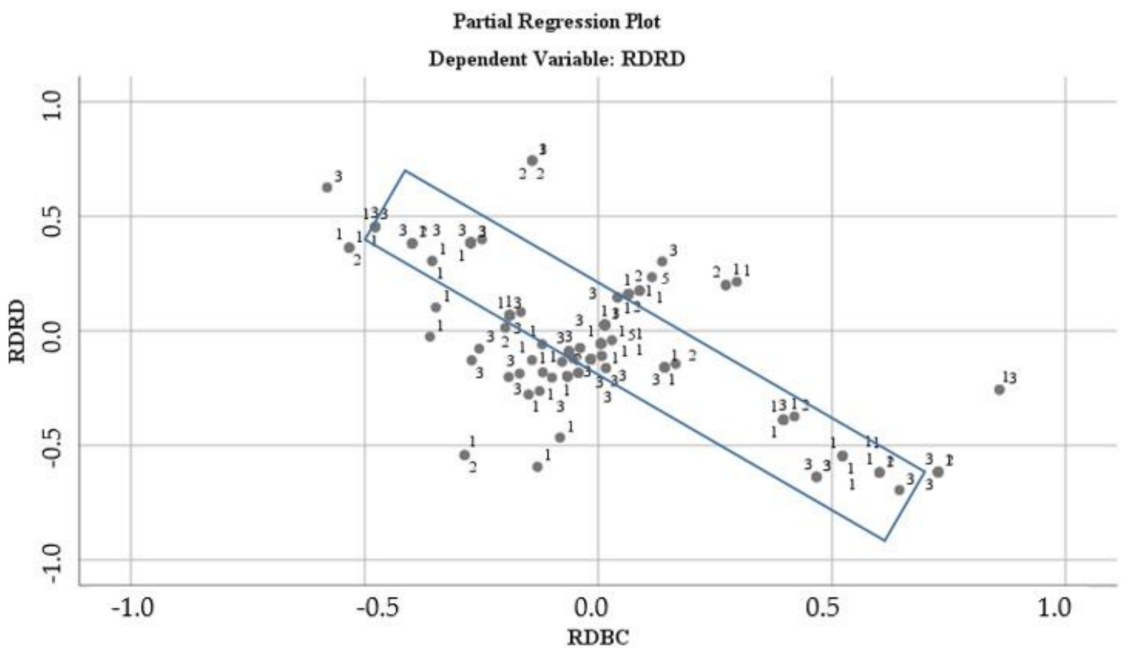

Figure 7. Regression analysis for RDBC.

The indicator concrete incentive measures, including financial-RDI, received a negative regression coefficient $(-0.790)$ via modelling. This coefficient represents a strong indirect correlation based on the functioning of the associative forms as a way of vitalizing rural development in Romania and is motivated by considerations of inefficiency in the use of funds and poor efficiency of the management of holding companies subject to financing. The trend distribution is bipolar, the bipolarity manifesting itself on the productive and commercial sectors (1 and 3), which means that in sector 1 , although a direct beneficiary of financing, the fructification of the financing activities does not represent a homogeneous feature of the system, but affects efficiency. This approach demonstrates objective 5 of the 
research: O5: Identifying the role of financial support for the development of holding companies and rural development (see Figure 8).

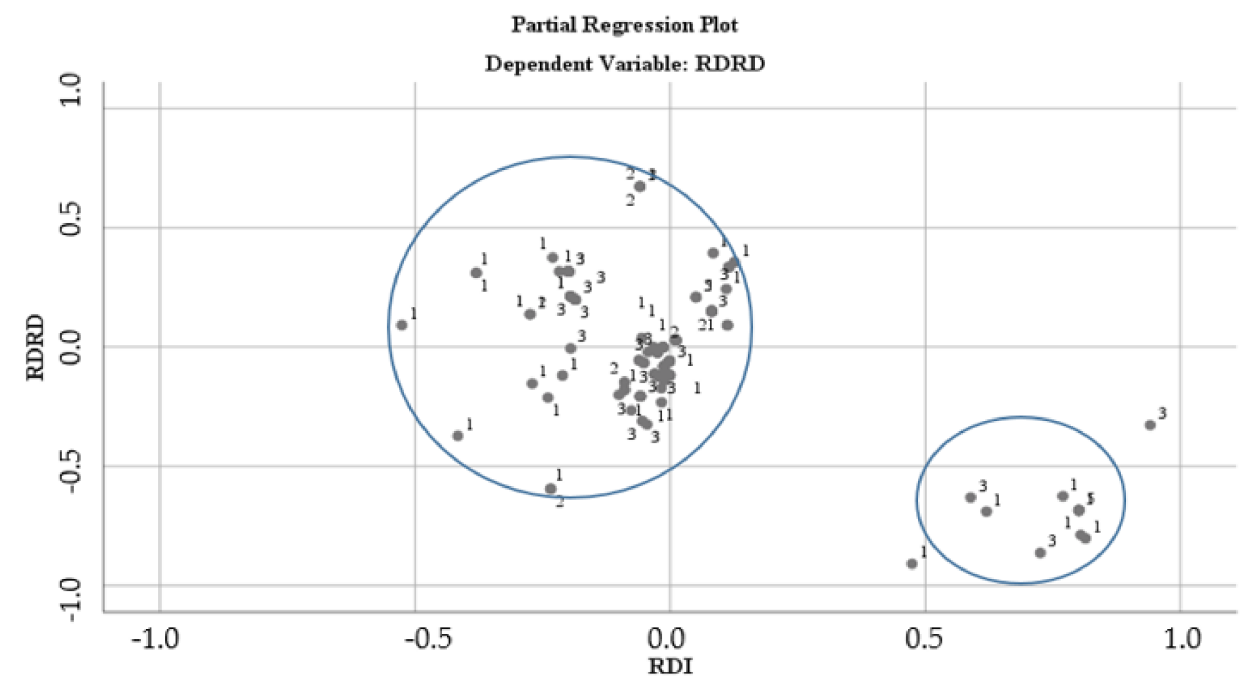

Figure 8. Regression analysis for RDI.

Another indicator which demonstrates the vulnerability of the associative forms in relation to the objective of maximizing rural economic development (Objective 3 ) is the opportunities to promote holding companies-OPAH. The level of the regression coefficient is minimal and negative (-0.034). It represents a weak indirect correlation regarding the opportunities to promote the holding companies as a measure of the rural development. The trend dynamics of the partial regression represents a bipolar distribution for the activities of production, processing and marketing of agricultural products (see Figure 9).

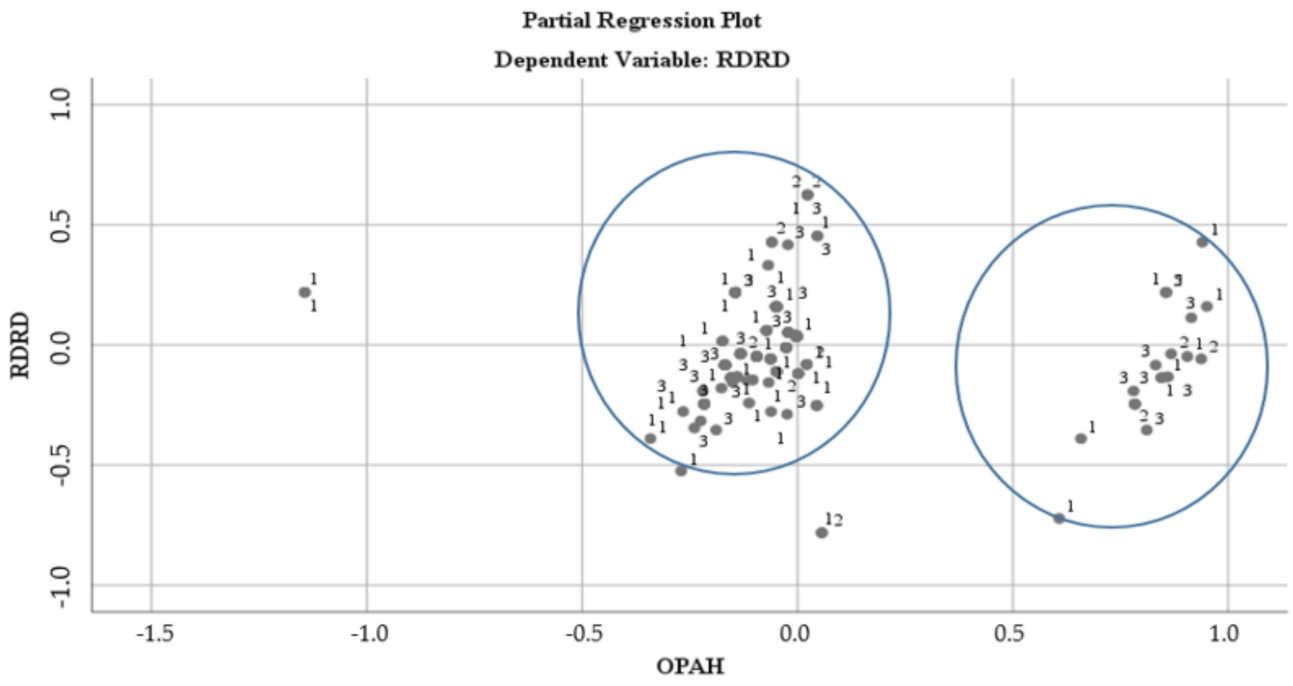

Figure 9. Regression analysis for $\mathrm{OPAH}$.

An impact indicator is the awareness of the need for concrete measures of the economic stimulation-PICI, an indicator which, after modelling, has assimilated a positive regression coefficient of 0.568 . This indicates a significant direct correlation regarding the concrete measures of economic stimulation as a unit of rural development. This measure is known by respondents and correctly assumed as a need for development. The bipolar trend indicator on the three activities (production, processing and marketing) answers to $\mathrm{O} 4$ of the research: Quantification of the rural development measures that reduce the identified vulnerabilities and maximize the development function (see Figure 10). 


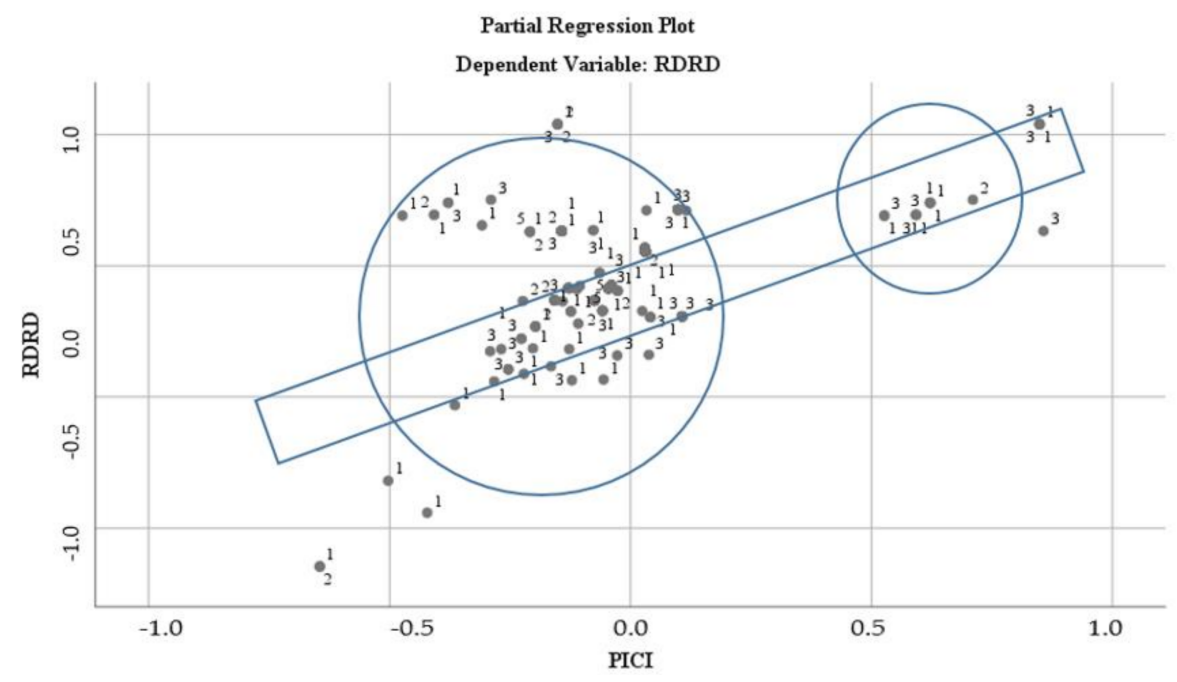

Figure 10. Regression analysis for PICI.

The vulnerability indicator discovered by modelling is the strategic cooperation with the authorities-RDSJ. The negative value of the regression coefficient $(-0.704)$ reflects a strong indirect correlation regarding strategic cooperation with the authorities as a measure of rural development, due to a weak confidence in the public administrative capacity and the impossibility of starting viable projects with it. There is a homogenization of vulnerability, where there is a small group of producers and traders which appreciate strategic cooperation as a solution for economic development. The approach corresponds to objective 3 of quantifying vulnerability, and motivates H1: The specific measures of rural development represent an effective way of state intervention in supporting local economic development if and only if they offer concrete measures of economic stimulation for at least $40 \%$ of the economic agents / associative forms in the region (see Figure 11).

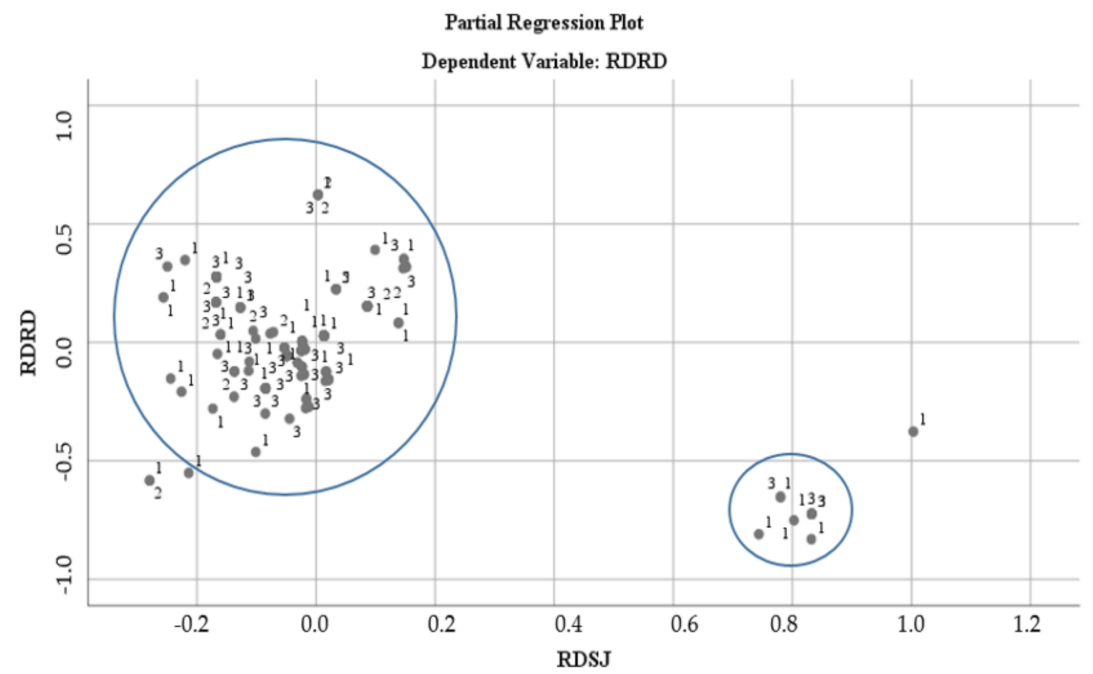

Figure 11. Regression analysis for RDSJ.

Promoting the transparency and traceability of the profession-PITT is one of the rural development measures that reduce the identified vulnerabilities and maximize the development function $(\mathrm{O} 4)$. The positive value of the regression coefficient $(0.516)$ indicates an average direct correlation regarding the promotion of the transparency and the traceability of the profession. It represents one of the viable options which the respondents from the administrative staff of the holding companies perceive regarding the effective development possibility for holding companies and rural development as a whole. The 
partial regression diagram shows an ascending trend with bipolar focus on the production and the marketing activities (see Figure 12).

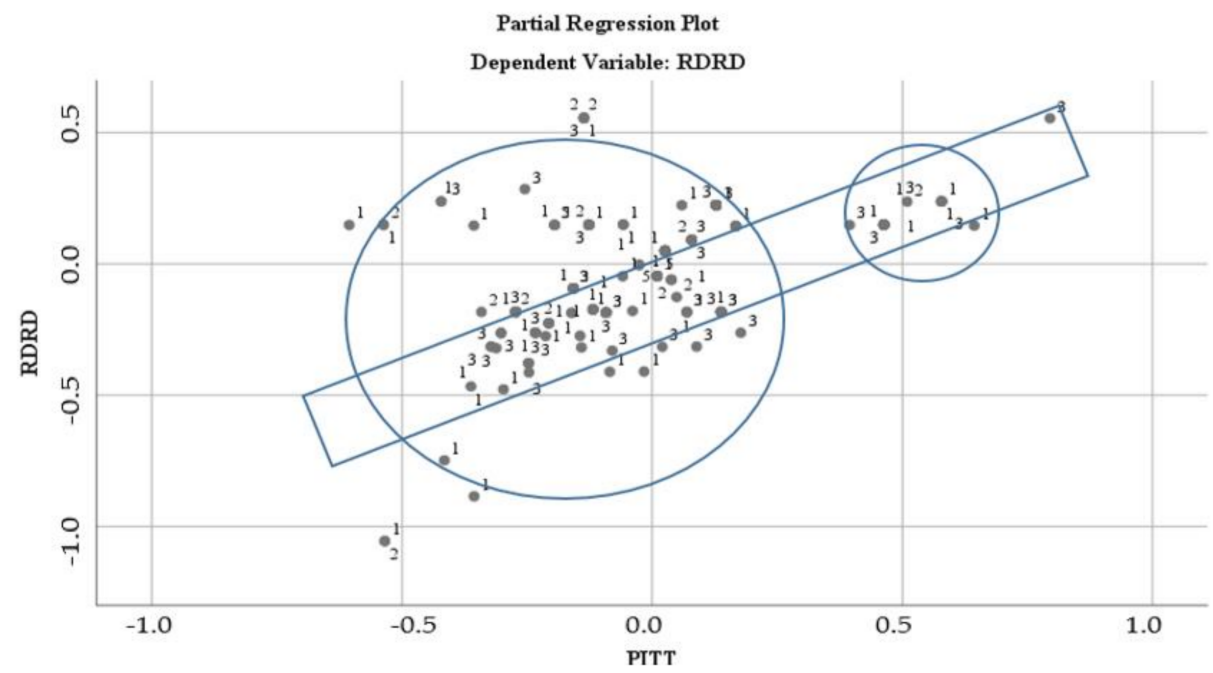

Figure 12. Regression analysis for PITT.

Strategic cooperation with other bodies than the authorities-PISP is part of the measures proposed in $\mathrm{O} 4$ to reduce vulnerabilities and has a value of the non-standard regression coefficient $\beta$ of 0.706 . This reflects a strong direct correlation on the strategic cooperation with bodies, other than public authorities, seen by respondents as a viable alternative to rural development (see Figure 13).

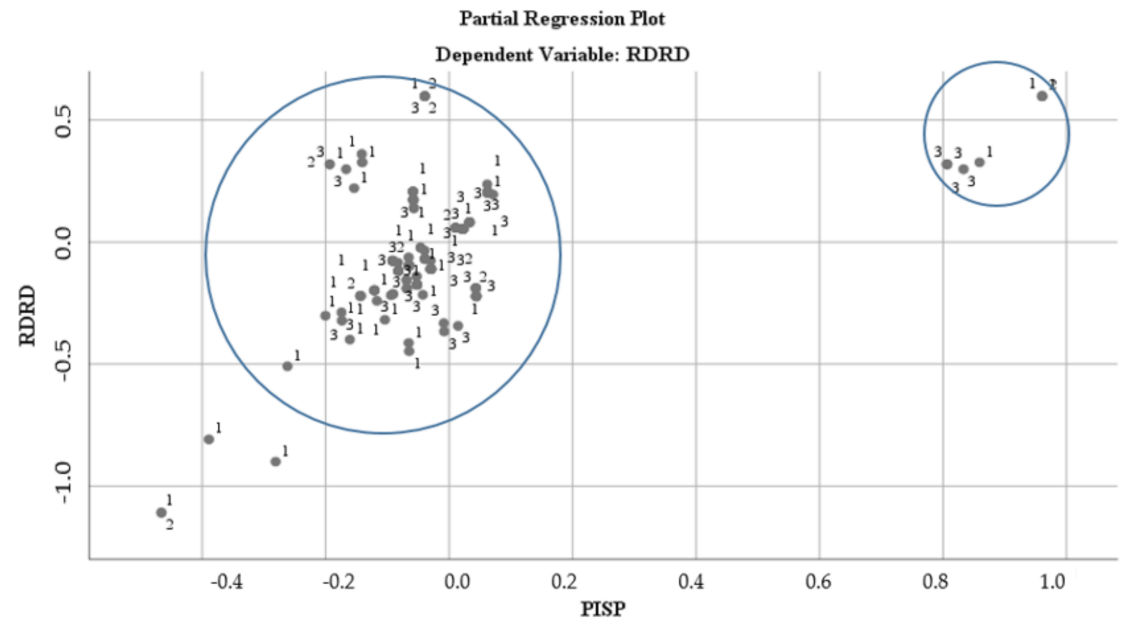

Figure 13. Regression analysis for PISP.

The implementation of viable regional development programs-PIRP is one of the impact measures which reduce the identified vulnerabilities and maximize the development function $(\mathrm{O} 4)$. The value of the regression coefficient is positive (0.616), representing a significant direct correlation regarding the contribution of the viable regional development programs, as a contribution for the rural development. The coefficient is a discredited coefficient based on the experience of Romanian holding companies in accessing and carrying out development programs, regardless of whether they were financed from their budget or from European Funds. However, the trend is positive, which means that under good management this measure would be a viable alternative for rural development. The partial regression diagram has a bipolar distribution and upward trend (see Figure 14). 


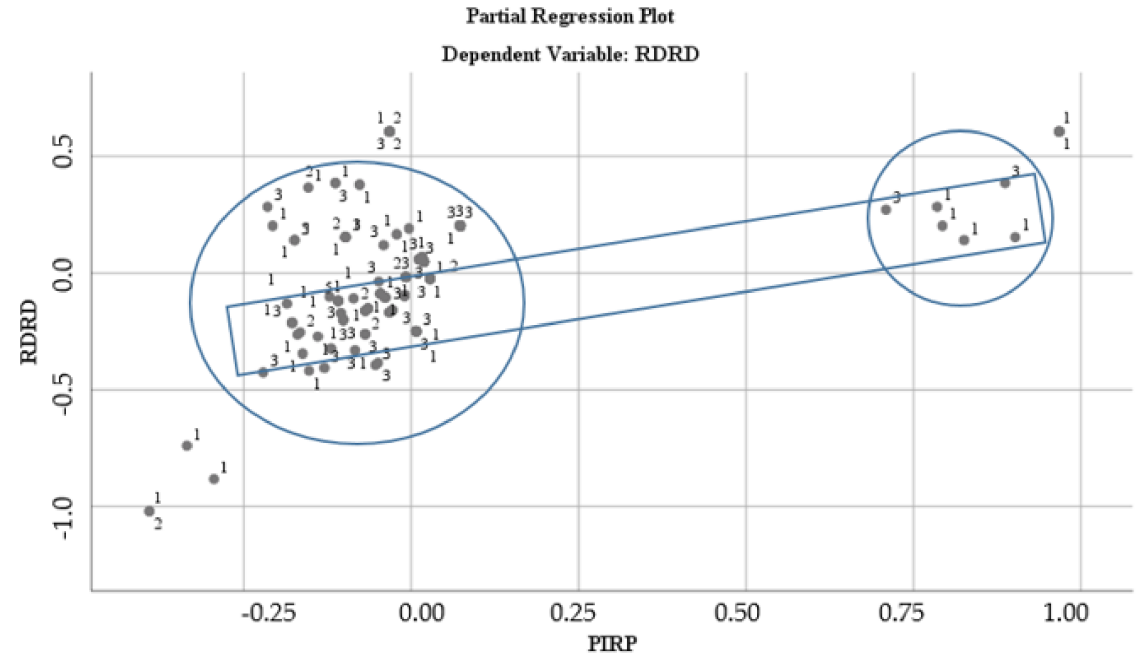

Figure 14. Regression analysis for PIRP.

Development of coherent agricultural policies-PIAP represents a viable solution (O4) under the conditions of a maximum correlation coefficient of 0.950 . Thus, a strong/ maximizing direct correlation is estimated, which indicates that, in the opinion of the respondents, the development of coherent agricultural policies represents the most efficient measure of rural development for Romania. The trend is unitary on the cluster and presents a normalized punctual evolution around the median value of the dependent variable indicator (see Figure 15).

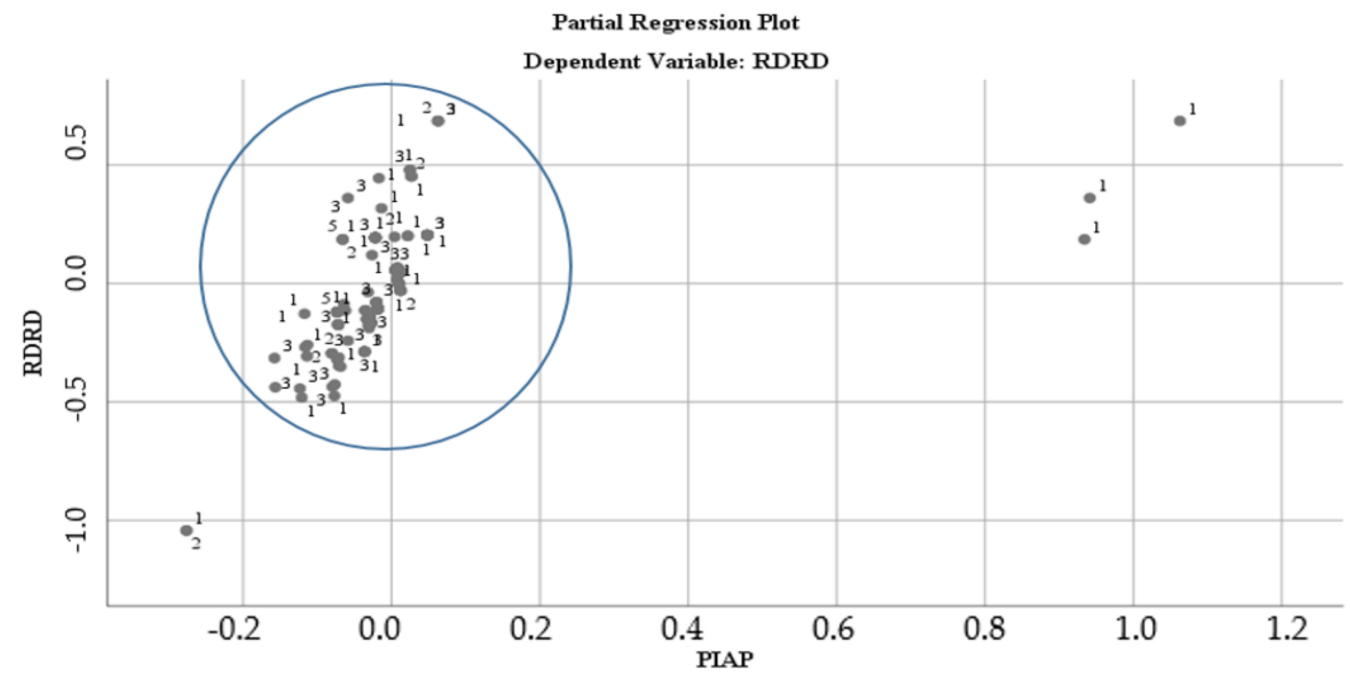

Figure 15. Regression analysis for PIAP.

Supply chain reduction-RDLC has a minimum negative correlation coefficient $(-0.062)$, which indicates an insignificant indirect correlation that reflects that the reduction of the supply chain is not an alternative for rural development.

RDLC showed the market mechanisms succeeding to streamline operational and commercial chains for carrying out agricultural activities in Romania. The trend is unitary on the cluster and presents a normalized punctual evolution around the median value of the dependent variable indicator (see Figure 16). 


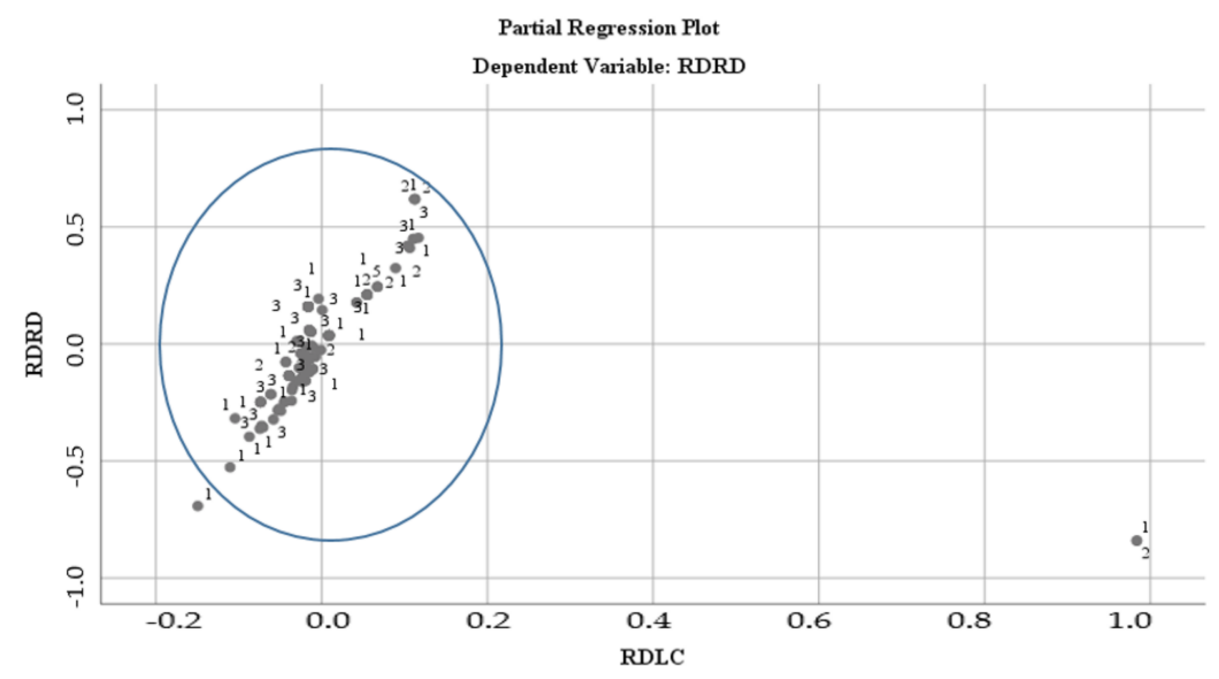

Figure 16. Regression analysis for RDLC.

\section{Conclusions}

Following research, we found that government financial support is a pivotal development tool for agricultural holding companies, provided that the support activity is focused on concrete measures that allow economic agents in the region to access and successfully implement the support measures.

The economic-financial framework becomes a tool for sustainability if it is periodically reviewed and improved and has an effect on the majority of holding companies in the region. Otherwise, it tends to become a disruptive factor that polarizes opportunities in favor of the regional leaders, discouraging free competition and reducing the region's sustainable agricultural dynamism.

According to the research, it resulted that, although associative forms represent an opportunity for rural development in Romania, they are not used efficiently, being identified during the research several vulnerabilities that affect the maximizing development function of holding companies. Among the elements of vulnerability, we identified the organizational aspects related to the holding companies, such as: promotion of the holding companies, dissemination of the benefits and obligations of the association, strategic cooperation with the authorities, involvement of the holding companies in regional cooperation programs and measures regarding the reduction of logistics chains.

On the other hand, the measures needed to strengthen the role of holding companies in rural development are: improving the legislative framework, adopting concrete measures of economic stimulation, economic fruition of support measures by transposing them into a sustainable economic growth of holding companies, improving strategic cooperation with other bodies than public authorities, promoting transparency and traceability of the profession, and intensifying the most viable measure, namely the development of coherent agricultural policies, which has, according to the developed model, a direct impact on rural development together with the development of viable programs at the regional level.

In this context, rural development becomes a pole of growth in terms of the good management of identified measures and in terms of reducing vulnerabilities through well-targeted policies and actions, with a stimulating effect for holding development and rural development. The limits of the study consist of the relatively limited number of the analyzed indicators. There may be other relevant indicators able to improve research findings. Moreover, the number of respondents to the questionnaire may be increased in a future approach.

The authors propose their extension to other significant aspects regarding rural development in future research. This future research will relate to the pandemic context and, by connecting to the sustainable dimension of agricultural holding development, including through the use of the IoT (Internet of Things), considering the study of [3] or Big Data. 
The authors state that there is no conflict of interest regarding the data used in the research.

Author Contributions: Data curation, A.M.F., F.B. and F.M.B.; Formal Analysis, R.V.I., M.L.Z. and V.M.A.; Investigation, A.M.F., F.B. and F.M.B.; Methodology, R.V.I., M.L.Z. and V.M.A.; Project Administration, F.M.B. and F.B.; Resources, A.M.F. and F.B.; Supervision, R.V.I. and V.M.A.; Writingoriginal draft, R.V.I., M.L.Z. and V.M.A. All authors have read and agreed to the published version of the manuscript.

Funding: This research was funded by “Dunărea de Jos" University of Galaţi, Romania.

Institutional Review Board Statement: Not applicable.

Informed Consent Statement: Not applicable.

Data Availability Statement: Not applicable.

Acknowledgments: The authors pay thanks to the Dunărea de Jos" University of Galaţi, Romania for support.

Conflicts of Interest: The authors declare no conflict of interest.

\section{References}

1. Apostolopoulos, N.; Chalvatzis, K.J.; Liargovas, P.G.; Newbery, R.; Rokou, E. The Role of the Expert Knowledge Broker in Rural Development: Renewable Energy Funding Decisions in Greece. J. Rural Stud. 2020, 78, 96-106. [CrossRef]

2. Kiryluk-Dryjska, E.; Beba, P.; Poczta, W. Local Determinants of the Common Agricultural Policy Rural Development Funds' Distribution in Poland and Their Spatial Implications. J. Rural Stud. 2020, 74, 201-209. [CrossRef]

3. Feng, W.; Liu, Y.; Qu, L. Effect of Land-Centered Urbanization on Rural Development: A Regional Analysis in China. Land Use Policy 2019, 87, 104072. [CrossRef]

4. Muresan, I.C.; Harun, R.; Arion, F.H.; Oroian, C.F.; Dumitras, D.E.; Mihai, V.C.; Ilea, M.; Chiciudean, D.I.; Gliga, I.D.; Chiciudean, G.O. Residents' Perception of Destination Quality: Key Factors for Sustainable Rural Development. Sustainability 2019, 11, 2594. [CrossRef]

5. Sabet, N.S.; Khaksar, S. The Performance of Local Government, Social Capital and Participation of Villagers in Sustainable Rural Development. Soc. Sci. J. 2020, 1-29. [CrossRef]

6. Han, J. Prioritizing Agricultural, Rural Development and Implementing the Rural Revitalization Strategy. China Agric. Econ. Rev. 2019, 12, 14-19. [CrossRef]

7. Gamso, J.; Yuldashev, F. Does Rural Development Aid Reduce International Migration? World Dev. 2018, 110, 268-282. [CrossRef]

8. Oya, C.; Schaefer, F.; Skalidou, D. The Effectiveness of Agricultural Certification in Developing Countries: A Systematic Review. World Dev. 2018, 112, 282-312. [CrossRef]

9. Mahmudov, B.J.; Bulturbayevich, M.B. Attracting Foreign Investment in the Agricultural Economy. Glob. Oppor. Index. 2015, 1, 2-4.

10. Mihaila, S.; Tanasa, S.-M.; Grosu, V.; Timofte (Coca), C. Integrated Reporting-An Influencing Factor on the Solvency and Liquidity of a Company and Its Role in the Managerial Decision-Making Process. In Proceedings of the Fourteenth International Conference on Management Science and Engineering Management, Chişinău, Moldova, 2020; pp. 783-794. [CrossRef]

11. Andrei, J.V.; Popescu, G.H.; Nica, E.; Chivu, L. The Impact of Agricultural Performance on Foreign Trade Concentration and Competitiveness: Empirical Evidence from Romanian Agriculture. J. Bus. Econ. Manag. 2020, 21, 317-343.

12. Salvioni, C.; Henke, R.; Vanni, F. The Impact of Non-Agricultural Diversification on Financial Performance: Evidence from Family Farms in Italy. Sustainability 2020, 12, 486. [CrossRef]

13. Agarwal, B.; Dorin, B. Group Farming in France: Why Do Some Regions Have More Cooperative Ventures than Others? Environ. Plan A Econ. Sp. 2019, 51, 781-804. [CrossRef]

14. Streletskaya, N.A.; Bell, S.D.; Kecinski, M.; Li, T.; Banerjee, S.; Palm-Forster, L.H.; Pannell, D. Agricultural Adoption and Behavioral Economics: Bridging the Gap. Appl. Econ. Perspect. Policy 2020, 42, 54-66. [CrossRef]

15. Kalogiannidis, S. Economic Cooperative Models: Agricultural Cooperatives in Greece and the Need to Modernize Their Operation for the Sustainable Development of Local Societies. Int. J. Acad. Res. Bus. Soc. Sci. 2020, 10, 2222-6990. [CrossRef]

16. Bohatereț, V.-M.; Brumă, I.; Tanasa, L. Comparative Study on the Profile of Agricultural Holdings without Legal Status in the Development Regions North-East and South-East of Romania. Agric. Econ. Rural Dev. 2018, 15, 93-113.

17. Clune, T. Conceptualising Policy for Sustainable Agriculture Development. Aust. J. Public Adm. 2021, 80, 493-509. [CrossRef]

18. Moghazy, N.H.; Kaluarachchi, J.J. Sustainable Agriculture Development in the Western Desert of Egypt: A Case Study on Crop Production, Profit, and Uncertainty in the Siwa Region. Sustainability 2020, 12, 6568. [CrossRef]

19. Dmytriieva, V.; Sviatets, Y. Turning Points in Agriculture Development in Ukraine: Results of Analysis on the Base of Purified Data. Agric. Resour. Econ. Int. Sci. E-J. 2021, 7, 5-21. [CrossRef] 
20. Loizou, E.; Karelakis, C.; Galanopoulos, K.; Mattas, K. The Role of Agriculture as a Development Tool for a Regional Economy. Agric. Syst. 2019, 173, 482-490. [CrossRef]

21. Yushkova, V.; Kostin, G.; Davydov, R.; Rud, S.; Dudkin, V.; Valiullin, L. The Development of Small and Medium-Sized Businesses, as the Basis for a Balanced Development of Agriculture in Russia. IOP Conf. Ser. Earth Environ. Sci. 2019, 390, 12016. [CrossRef]

22. Tatarintsev, M.; Korchagin, S.; Nikitin, P.; Gorokhova, R.; Bystrenina, I.; Serdechnyy, D. Analysis of the Forecast Price as a Factor of Sustainable Development of Agriculture. Agronomy 2021, 11, 1235. [CrossRef]

23. Szafranska, B.; Busko, M.; Kovalyshyn, O.; Kolodiy, P. Building a Spatial Information System to Support the Development of Agriculture in Poland and Ukraine. Agronomy 2020, 10, 1884. [CrossRef]

24. Streimikis, J.; Baležentis, T. Agricultural Sustainability Assessment Framework Integrating Sustainable Development Goals and Interlinked Priorities of Environmental, Climate and Agriculture Policies. Sustain. Dev. 2020, 28, 1702-1712. [CrossRef]

25. Tohidyan Far, S.; Rezaei-Moghaddam, K. Multifunctional Agriculture: An Approach for Entrepreneurship Development of Agricultural Sector. J. Glob. Entrep. Res. 2019, 9, 23. [CrossRef]

26. Boyabatlı, O.; Nasiry, J.; Zhou, Y. Crop Planning in Sustainable Agriculture: Dynamic Farmland Allocation in the Presence of Crop Rotation Benefits. Manag. Sci. 2019, 65, 2060-2076. [CrossRef]

27. Laurett, R.; Paço, A.; Mainardes, E.W. Sustainable Development in Agriculture and Its Antecedents, Barriers and ConsequencesAn Exploratory Study. Sustain. Prod. Consum. 2021, 27, 298-311. [CrossRef]

28. Velten, S.; Jager, N.W.; Newig, J. Success of Collaboration for Sustainable Agriculture: A Case Study Meta-Analysis. Environ. Dev. Sustain. 2021, 23, 14619-14641. [CrossRef] 